\begin{tabular}{|c|c|c|c|c|c|c|}
\hline \multirow{4}{*}{ Impact Factor: } & ISRA (India) & $=3.117$ & SIS (USA) & $=0.912$ & ICV (Poland) & $=6.630$ \\
\hline & ISI (Dubai, UAE & $=0.829$ & РИНЦ (Russia & $=0.156$ & PIF (India) & $=1.940$ \\
\hline & GIF (Australia) & $=0.564$ & ESJI (KZ) & $=8.716$ & IBI (India) & $=4.260$ \\
\hline & JIF & $=1.500$ & SJIF (Morocco & $=\mathbf{5 . 6 6 7}$ & OAJI (USA) & $=0.350$ \\
\hline
\end{tabular}

\begin{tabular}{|c|c|}
\hline \multicolumn{2}{|c|}{$\begin{array}{l}\text { SOI: } \underline{1.1 / \mathrm{TAS}} \text { DOI: } \underline{10.15863 / \mathrm{TAS}} \\
\text { International Scientific Journal } \\
\text { Theoretical \& Applied Science }\end{array}$} \\
\hline p-ISSN: 2308-4944 (print) & e-ISSN: 2409-0085 (online) \\
\hline Year: 2019 & Volume: 72 \\
\hline Published: 14.04 .2019 & Attp://T-Science.org \\
\hline
\end{tabular}

SECTION 11. Biology. Ecology. Veterinary. UDC: 581.582.477.6. (575.111)
QR - Issue

QR - Article

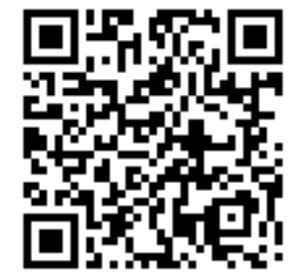

Uktam Eshtemirovich Khujanazarov Candidate of Biological Sciences Acting Associate Professor of the Department "Botany"

Dustmakhmat Tashmatovich Bakiyev Candidate of Biological Sciences Acting Associate Professor of the Department "Botany", Tashkent state pedagogical university named after Nizami, Uzbekistan

\title{
ECOLOGICAL PRINCIPLES OF RESTORATION OF DEGRADED PASTURES IN KASHKADARYA BASIN
}

\footnotetext{
Abstract: This paper involves restoration principles of pastures in degraded territories of Kashkadarya basin and received data are based on the floristic and cenotic principles in pastures, besides restoration process includes of the principle of ecological-cenotic depency of pasture ecosystems, adaptive strategy of plants and differentiation principles of ecological nicha based on various species of complementary, ecotypes and plant species on the basis of pasture phytocenosis formation.

Key words: pasture, degradation, Kashkadarya basin, plant, cattle, grazing, ecology, principles, steppe, restoration.

Language: Russian

Citation: Khujanazarov, U. E., \& Bakiyev, D. E. (2019). Ecological principles of restoration of degraded pastures in Kashkadarya basin. ISJ Theoretical \& Applied Science, 04 (72), 161-164.

Soi: http://s-o-i.org/1.1/TAS-04-72-20 Doi: crossef https://dx.doi.org/10.15863/TAS.2019.04.72.20
}

\section{Introduction}

The Kashkadarya region includes of Karshi depression in southern Uzbekistan, bordered in the north by the mountains of Koratepa, Zirabulok, Ziyevuddin, in the east - by the foot of the southwestern part of the Gisar ridge [2]. As a result of the study, we analyzed a plant of mountain pastures and determined the current state of pastures in the Kashkadarya basin. The territory belongs to the temperate climatic zone. The climate is dry continental with long, hot and dry summer season; the winter season is short with mild frosts and little snow. The average annual temperature is $13^{\circ} \mathrm{C}-14^{\circ} \mathrm{C}$, the average temperature of January is $0^{\circ} \mathrm{C}-2^{\circ} \mathrm{C}$, average temperature of the July is $26^{\circ} \mathrm{C}-28^{\circ} \mathrm{C}$, the annual precipitation is $400-600 \mathrm{~mm}$ [10]. Restoration of the semi-arid shrub-steppe ecosystem has gained increasing attention over the last 20 years. This is the result of growing recognition of the values intact shrub-steppe ecosystems provide to communities. Soil stabilization may be the highest value of intact shrub steppe [7]. Intact shrub-steppe ecosystems also moderate wildfire spread, while disturbed shrubsteppe ecosystems dominated by invasive cheat grass
(Bromus tectorum) cause increased fire frequency and intensity. In addition to increasing risk to lives and property, increased fire causes further loss of big sagebrush (Artemisia tridentata), the dominant plant in this ecosystem [9]. Intact shrub-steppe with sagebrush is needed as habitat for a number of birds [8], such as the sage grouse [1], which is now rare. Highly diverse communities dominated by native plant species are likely to be more productive [5] and thus support more diverse wildlife.

\section{Materials and Methods}

We rely to the fundamental conditions of ecology to restore degraded pasture agrolandscapes and this process is based on the floristic and cenotic principles in pastures, besides restoration process involves the principle of ecological-cenotic depency of pasture ecosystems, adaptive strategy of plants and differentiation principle of ecological nicha based on various species of complementary, ecotypes and plant species on the basis of pasture phytocenosis formation.

The type and number of variables comprising the dimensions of an environmental niche vary from one 


\begin{tabular}{|c|c|c|c|c|c|c|}
\hline \multirow{4}{*}{ Impact Factor: } & ISRA (India) & $=3.117$ & SIS (USA) & $=0.912$ & ICV (Poland) & $=6.630$ \\
\hline & ISI (Dubai, UAE & $=0.829$ & РИНЦ (Russia & $=\mathbf{0 . 1 5 6}$ & PIF (India) & $=1.940$ \\
\hline & GIF (Australia) & $=0.564$ & ESJI (KZ) & $=8.716$ & IBI (India) & $=4.260$ \\
\hline & JIF & $=1.500$ & SJIF (Morocco & $=5.667$ & OAJI (USA) & $=0.350$ \\
\hline
\end{tabular}

species to another [and] the relative importance of particular environmental variables for a species may vary according to the geographic and biotic contexts [6].

Uzbekistan, a part of which is the Kashkadarya basin forests, is also diverse. The unique geomorphologic structure and climatic conditions of the Kashkadarya basin, that the diversity of natural conditions are essential and these determine the richness of region's flora, seasonal and regional distribution are specific for the basin [4]. It is important to create phytocenosis, which has potential opportunity as a result of the abundance of cattle in the pastures. In this process, it is necessary to plant the pasture shrubs, semi shrubs and herbs together as a quality semi-cultures. Using this mixture of plants new ecological niches for other plants are created.

Compatibility of ecologically-cenotic constructions and principles of adaptive strategies of plants. The zone types of biogeocenotic structures are based on the vital forms of plants. The main builder of biogeocenotic structure in semi desert and dry steppes is semi bushes (Artemisia genus species, Kochia, perennial plant species in Camphorosma genus and others) and perennial herbs (Agropyron, Stipa, Elymus, etc.). In 1925, L. G. Ramenskiy applied three adaptive strategies in plants: violents, patients and explerents. Later Dj.Graym divided on the following anological types of life strategies: concurents (C), stress-tolerants $(\mathrm{S})$ and ruderals $(\mathrm{R})$.

Violent plants develop energetically good, occupy territories and can store for themselves. We can estimate the following plants such as Artemisia sp., Kochia prostrata, Agropyron spp. and Poa bulbosa.

Patients are resistant to the conditions and grow in conditions of insufficient limiting factors such as moisture or nutritional elements, light and heat. These are: Salsola orientalis, Climacoptera lanata and Artemisia turanica.

The explerents have a small competitive power, but they quickly occupy space places. They change the place with violents. Explerents include of Bromus tectorum, Eremopyrum orientale, Strigosella grandiflora, Trigonella grandiflora and others.

Thus, we can give a conclusion, it is recommended to culture adaptive strategic plants in various types having optimal phytocenotic balance for the recovery of degraded pastures to preserve high productivity and stability. In order to maintain the productivity of the pasture and the stability of the plant communities, first of all it is necessary to select plants with violent characteristics. Patient-type plants are sown on non-critical areas. Of course, the patient type plants of adaptive strategy is widely spread in fodder pastures. Explerents, for example, ephemeras, annuals are used to form mosaic pasture ecosystems, creating long-term pastures, to create semi bushes and perennials in horizon, seasonal and succession forms, the ephemeras are applied from sowing until virgil periods.

The principle of differentiation of ecological niche and mutually complementary species in phytocenoses. The differentiation of ecological niche during restoration of degraded pasture ecosystems is carried out in the various rhythmic season development periods (root, branch, etc.) by providing with mineral nutrients and lighting on soil of various organs of plant species and on the surface of the earth. In this process, the most important task of defining the methods and directions of ecological recovery is the study of the life forms, species and ecotypes of forage crop plants together. Some data on the chemical composition of dark brown soil and brown soil are given in dry soil composition as percentage (Table 1).

As shown in Table 1, due to the large influence of anthropogenic factors in the pastures, it has led to a reduction in humus content in the soil. This leads to the decline in pasture yields and to the degradation of the ecological situation - the transformation of the pasture types, it develops to increase of desertification process.

Table 1. To define the transformation of pasture types according to soil composition.

\begin{tabular}{|c|c|c|c|c|c|c|}
\hline Time & $\begin{array}{l}\text { Soil tearing } \\
\text { (cutting) }\end{array}$ & Soil type & $\begin{array}{l}\text { Depth, } \\
\text { cm }\end{array}$ & Humus & Nitrogen & $\mathrm{CO}_{2}$ \\
\hline 1937 & $\begin{array}{l}\text { N } 5 \\
\text { S.A.Shuvalov }\end{array}$ & $\begin{array}{l}1100 \mathrm{~m} \text { above sea level, } \\
\text { natural grass cover, gray } \\
\text { soils, West Zerafshan }\end{array}$ & $\begin{array}{l}0-10 \\
15-25 \\
50-60\end{array}$ & $\begin{array}{l}2,66 \\
1,76 \\
0,55\end{array}$ & $\begin{array}{l}- \\
- \\
-\end{array}$ & $\begin{array}{l}2,15 \\
6,36 \\
16,64\end{array}$ \\
\hline 1937 & $\begin{array}{l}\text { N } 2 \\
\text { S.A.Shuvalov }\end{array}$ & $\begin{array}{l}1100 \mathrm{~m} \text { above sea level in } \\
\text { gray soils, Akhchadil, } \\
\text { West Zerafshan }\end{array}$ & $\begin{array}{l}0-6 \\
6-12 \\
15-25 \\
50-60\end{array}$ & $\begin{array}{l}3,84 \\
3,10 \\
1,21 \\
0,71\end{array}$ & $\begin{array}{l}0,29 \\
0,28 \\
0,15\end{array}$ & $\begin{array}{l}1,07 \\
0,98 \\
1,17 \\
8,91\end{array}$ \\
\hline
\end{tabular}




\begin{tabular}{|c|c|c|c|c|c|c|}
\hline \multirow{4}{*}{ Impact Factor: } & ISRA (India) & $=3.117$ & SIS (USA) & $=0.912$ & ICV (Poland) & $=6.630$ \\
\hline & ISI (Dubai, UAE & $=0.829$ & РИНЦ (Russia & $=\mathbf{0 . 1 5 6}$ & PIF (India) & $=1.940$ \\
\hline & GIF (Australia) & $=0.564$ & ESJI (KZ) & $=8.716$ & IBI (India) & $=4.260$ \\
\hline & JIF & $=1.500$ & SJIF (Morocco & $=\mathbf{5 . 6 6 7}$ & OAJI (USA) & $=0.350$ \\
\hline
\end{tabular}

\begin{tabular}{|c|c|c|c|c|c|c|}
\hline 1956 & $\begin{array}{l}\text { In Chirakchi } \\
\text { district in stage } \\
\text { of gray soil } \\
\text { N.T.Muraveva }\end{array}$ & $\begin{array}{l}\text { South-western Zarafshan } \\
\text { gray soil mountain slopes }\end{array}$ & $\begin{array}{l}10-18 \\
18-33 \\
33-40 \\
40-33 \\
53-60\end{array}$ & $\begin{array}{l}2,24 \\
1,51 \\
1,32 \\
0,13 \\
0,85\end{array}$ & $\begin{array}{l}0,143 \\
0,122 \\
0,124 \\
0,093 \\
0,075\end{array}$ & $\begin{array}{l}- \\
- \\
- \\
- \\
-\end{array}$ \\
\hline 1997 & $\begin{array}{l}\text { N } 4 \\
\text { Yu.S.Vakhidov, } \\
\text { U.Khujanazarov }\end{array}$ & $\begin{array}{l}\text { South-western Zarafshan, } \\
4.5 \mathrm{~km} \text { above the Tutli } \\
\text { village, gray soil }\end{array}$ & $\begin{array}{l}0-10 \\
15-20 \\
20-30 \\
30-50 \\
\end{array}$ & $\begin{array}{l}2,10 \\
1,53 \\
1,41 \\
0,90\end{array}$ & $\begin{array}{r}0,22 \\
0,20 \\
0,15 \\
-\end{array}$ & $\begin{array}{l}1,03 \\
3,45 \\
2,50 \\
4,5 \\
\end{array}$ \\
\hline 2011 & $\begin{array}{l}\text { K } 11 . \\
\text { L.Tursunov, } \\
\text { U.khujanazarov }\end{array}$ & $\begin{array}{l}\text { Kitob district, } \\
\text { Bodomzor village, brown } \\
\text { soil }\end{array}$ & $\begin{array}{l}0-6 \\
6-20 \\
20-50 \\
50-80\end{array}$ & $\begin{array}{l}2,63 \\
2,15 \\
0,91 \\
0,52\end{array}$ & $\begin{array}{l}- \\
- \\
- \\
-\end{array}$ & $\begin{array}{l}3,32 \\
7,61 \\
11,55 \\
10\end{array}$ \\
\hline
\end{tabular}

\section{Conclusion}

As a result of the geobotanical studies carried out in the slopes of Kashkadarya basin, 14 pastures have been found to be distributed, their structure (lifestyle), classification, distribution laws, transformation in large-scale mapping, and their change levels were studied and this index is $45-50$ percent [3].

The map of the pastures is a scientific document, consisting of a geobotanical content of the district pastures, a combination of the distribution law, the area, the ecological status, the degree of distribution, the availability of the season. This map can be used to plan pastures, use plant raw materials, and protect nature conservation.

This research includes of cultivating plant species in different soil and climatic conditions and it is of great importance in the cultivation of plain - semi desert, mountain foothill slopes, and low mountain belts. We have defined to plant the species of plants in studied area which this research showed the identification of the ecological groups of plants. These are hyperxerophytes are highly drought - resistant xerophytes (black haloxylon, salsola, etc.); xerophytes - true xerophytes (species of Kochia, Krascheninnikovia); teroiremoxerophytes xerophytes during summer tense period (species of Artemisia); hemixerophytes - half xerophytes (species of Alhagi); xeromesophytes - xerophilic mesophytes (species of Onobrychis, Melilotus) and mesophytes - are plants that are adapted to the average moisture content (species of Poa, Bromus, etc).

\section{References:}

1. Connelly, J. W., \& Braun C. E. (1997). Longterm changes in sage grouse Centrocerus urophasianus populations in western North America. Wildlife Biology 3: 229-234.

2. (1959). Kashkadarya Region. Part I. Nature, Proceedings SASU, Geographical Science. (p.279). Tashkent: SASU.

3. Khujanazarov, U. E. (2017). A statistical analyze of pasture plants of Kashkadarya basin foothills. European science review, № 11-12, Austria, pp. 26-28.

4. Khujanazarov, U. E., Yu-Mi, Lee, \& Sadinov, J. S. (2019). A transformation of foothills of South Uzbekistan (in the sample of Kashkadarya basin). International Journal of Scientific and Research Publications, Volume 9, Issue 4, April 2019. ISSN 2250-3153. pp.149-151.
5. Naeem, S., Thompson, L. J., Lawler, S. P., Lawton, J. H., \& Woodfin, R. M. (1995). Empirical evidence that declining species diversity may alter the performance of terrestrial ecosystems. Phil. Trans. R. Soc. Lond. B 347: 249-262.

6. Rogers, L. E., \& Rickard, W. H. (1988). Introduction: Shrub-steppe lands. Pp. 112 in W. H. Rickard, L. E. Rogers, B. E. Vaughan and S. F. Liebetrau (Eds.). Shrub-steppe: balance and change in a semi-arid terrestrial ecosystem. Elsevier, Amsterdam.

7. Scott, M. J., et al. (1998). Valuation of ecological resources and functions. Environmental Management: 49-68.

8. Peterson, T., et al. (2011). Species-environment relationships. Ecological Niches and 


\begin{tabular}{|c|c|c|c|c|c|c|}
\hline \multirow{4}{*}{ Impact Factor: } & ISRA (India) & $=3.117$ & SIS (USA) & $=0.912$ & ICV (Poland) & $=6.630$ \\
\hline & ISI (Dubai, UAE & $=0.829$ & РИНЦ (Russia & $=0.156$ & PIF (India) & $=1.940$ \\
\hline & GIF (Australia) & $=0.564$ & ESJI (KZ) & $=8.716$ & IBI (India) & $=4.260$ \\
\hline & JIF & $=1.500$ & SJIF (Morocco & $=5.667$ & OAJI (USA) & $=0.350$ \\
\hline
\end{tabular}

Geographic Distributions (MPB-49). Princeton University Press. p. 82. ISBN 9780691136882.

9. Whisenant, S. G. (1990). Changing fire frequencies on Idaho's Snake River plains: ecological and management implication. USDA
Forest Service Intermountain Research Station General Technical Report: INT-276:4-10.

10. Williams, M. W. \& Konovalov, V. G. (2008). Central Asia Temperature and Precipitation Data. Boulder, Colorado: USA National Snow and Ice Data Center, 1879-2003. 